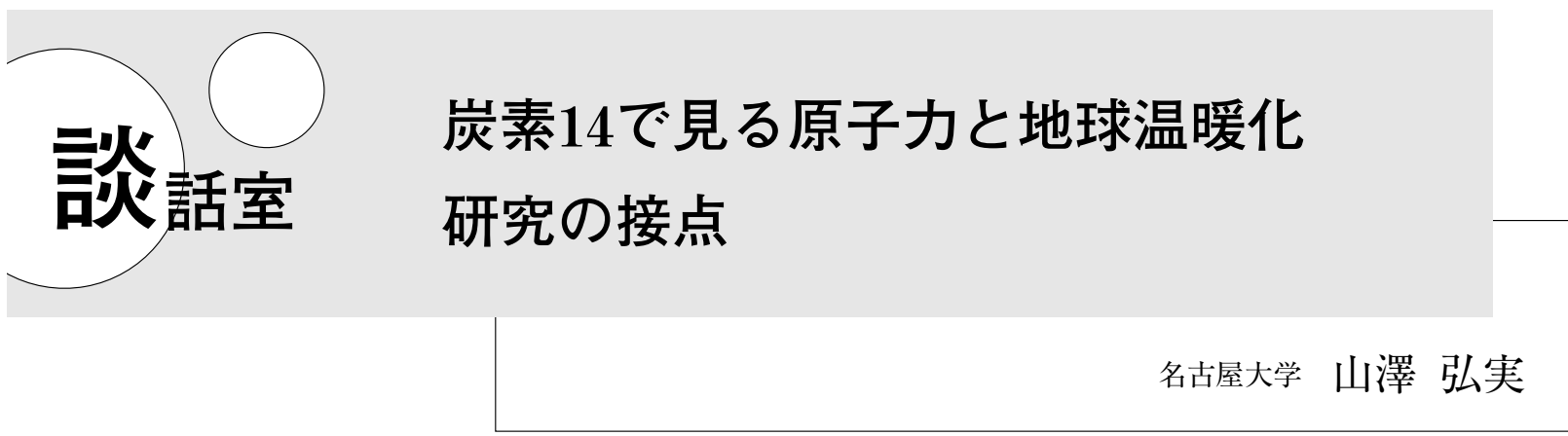

\section{「地球温暖化は本当 ?」の今昔}

過去四半世紀で地球温暖化問題の切迫度に対する認識 は大きく変化した。筆者が大学院生であった四半世紀 前，気候物理研究の世界的第一人者の講義の中での「地 球の平均気温は過去100年の間に上昇しているように見 え, 大気中二酸化炭素の濃度上昇に伴う温暖化の可能性 が高いが，そう結論づけるためにはさらに10年，20年注 視する必要がある」との言葉が今なお記憶に残ってい る。温室効果自体はすでに約一世紀前に物理化学分野の 著名な研究者 S.V. Arrheniusにより提唱され, 講義当 時では地球温暖化メカニズムの研究が相当進んでいた。

しかし，実際に起こっているかについては半信半疑の専 門家も少なくなかった。

それが今から 10 年以上前には，多くの観測事実や数值 モデル予測に基づく「気候変動に関する政府間パネル (IPCC) 報告書」にまとめられたように，地球温暖化は現 在の文明社会が直面する最大の問題として専門家のみな らず，政策決定者の間でも広く認識されるようになっ た。議論の対象は，その大きさ，速さおよび社会的影響 の理解と, 温室効果ガスの排出抑制㧍よび気候変動の緩 和策に移っている。このような背景で, エネルギー供給 源として原子力の役割の認識が近年, 社会で増してき た。

\section{地球温暖化分野：炭素14で炭素動態を追う}

気候変動を定量的に評価する上で重要となるのは フィードバック機構の理解である。炭素が係わるものと して, 温度上昇に伴う海洋の二酸化炭素吸収量の減少, 土壤有機物分解の増加, 植物成長の長期化等がある。前 二者は温暖化を促進する正の, 後者は負のフィードバッ クとなる。負の働きとして大気中二酸化炭素濃度増加に 伴う光合成の高効率化も挙げられる。これらの機構の理 解の不十分さが気候変動予測の不確実さの大きな要因と なっているため, 地表面が関与する炭素循環に関する研 究が数多く進められているのが現状で, その際炭素 14 $\left({ }^{14} \mathrm{C}\right)$ を含む炭素同位体がトレーサとして利用される。

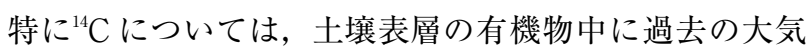
圈核実験に起因する比較的高い同位体比が見られ，炭素 動態を追う上での便利な「目印」となっている。核実験後
の大気中 ${ }^{14} \mathrm{CO}_{2}$ 濃度が高い時期に光合成により ${ }^{14} \mathrm{C}$ が植物 に固定され，落葉・落枝により土壤有機物となったもの である。ただし，この目印も形成された後 40 年以上経過 して不鮮明になりつつあり，10年後には，特に温暖地で はその有用性もかなり低下してしまうものと考えられ る。

\section{原子力分野：炭素14そのものを追う}

一方, 原子力の保健物理・環境科学分野においては, 被ばく評価の観点から, ${ }^{14} \mathrm{C}$ の環境中移行が研究されて いる。UNSCEAR 2000年レポートによると， ${ }^{14} \mathrm{C}$ は原子 炉の運転および使用済燃料の再処理の過程で環境中に放 出される核種の中で集団線量への寄与が最も大きい核種 とされ，我が国においても使用済燃料再処理施設の本格 稼働を控え，より現実に即した被ばく評価を行う上で $\mathrm{C}$ 環境中移行研究の必要性が高まっている。主要な被ばく 経路は，二酸化炭素として大気中に放出された ${ }^{14} \mathrm{C}$ が光 合成により農作物に吸収され，それが直接あるいは食物 連鎖を経て経口摂取される経路である。大気中に放出さ れた後は，環境中での炭素循環に取り込まれ，核分裂生 成核種とは全く異なる極めて動的な移行挙動を取る。し たがって，被ばく評価に扔いてもその様な動的な振る舞 いを取り扱うことになり，その点では地球温暖化を対象 とした炭素循環研究との共通点が多い。

\section{それぞれに研究が進む地球温暖化分野と原子力分野}

このように着目する現象は同じであっても，両分野で の炭素動態に関する研究は独立に行われているという印 象が強い。これは，最終的に評価しなければならない対 象が両分野で異なること, 研究成果が流通する舞台(学 会, 専門誌)が異なること, したがって研究者間の交流 が少ないことが主な要因であろう。これまでの研究知見 の蓄積度から観ると, 気象学 (微気象学, 農業気象学等) や農学(森林学, 土壌学, 作物学, 植物生理学等)を取り 込んでいる地球温暖化分野の方が圧倒的に層が厚い。し たがって，原子力分野に押いては，地球温暖化分野での 先行研究から知見を取り入れることが有効な手段の一つ となるが， ${ }^{14} \mathrm{C}$ 移行を評価する上で必要な直接的な知見 が得られることは必ずしも多くない。例えば， ${ }^{14} \mathrm{CO}_{2} か ゙$ 
存在する空気に作物を暴露した場合, 最終的に農作物 (特 に可食部)に蓄積する ${ }^{14} \mathrm{C}$ の量が被ばく評価で必要となる が, 地球温暖化分野から得られる情報の多くは光合成に よる吸収量から呼吸による放出量を差し引いた正味の炭 素吸収量である。この情報でもかなり有用ではあるが, 吸収された ${ }^{14} \mathrm{CO}_{2}$ の量を評価する上で十分ではない。と いって,より詳細に扱扔うと植物生理の知見を利用し て, 温湿度, 土壤水分量, 光合成有効放射量に敏感に反 応する気孔抵抗まで踏み込んでしまうと, 普遍性の高い 結果を得るのに膨大な労量を割くことになる。

\section{両分野での知見の共有をめざした企画を開催}

それでは, 兩分野は観点が異なり, 接点は少ないので あろうか。筆者は必ずしもそのようには考えていない。 上の例で正味の吸収量を評価するために，炭素同位体を 利用した実験や解析が行われることが多く，まさに ${ }^{14} \mathrm{CO}_{2}$ 吸収量を評価するのに十分な知見が得られている。しか しそのような知見は，正味の吸収量を評価することを目 的とした研究では, 途中段階の結果であり, 論文等の流 通する知見として表面に現れにくい。研究者間の交流を 通して始めて手に入る情報となっている。原子力分野に そのようなニーズがあることが地球温暖化分野の研究者 には認知されていないのである。

原子力分野と地球温暖化分野の 2 局に単純化して記述 してきたが，環境中炭素循環に関する研究は，実際には 農学や環境学の観点からさらに多くの分野で行われてい る。原子力分野の ${ }^{14} \mathrm{C}$ 移行研究の目的を達する上では, 関連する分野との交流が効果的であることは前述のとお り明らかである。この考えから, 当学会の保健物理・環 境科学部会は2006年秋の大会で「炭素14の環境中移行研 究の現状と今後の展開」と題する部会企画セッションを 開催した。その中ではセラフィールド再处理施設周辺の 樹木年輪中の ${ }^{14} \mathrm{C}$ を分析することにより施設からの ${ }^{14} \mathrm{C}$ 放 出量を再評価する研究や, 再处理施設から放出される ${ }^{14} \mathrm{C}$ の移行を想定した閉鎖型生態系実験施設を用いての大気 一食物ーヒト間の ${ }^{13} \mathrm{C}$ 移行実験といった原子力分野に直 結した研究の現状が議論された。後者は, 施設の制約で 使えない放射性の ${ }^{14} \mathrm{C}$ の代わりとして ${ }^{13} \mathrm{C}$ 用いた研究で ある。一般環境研究で $\mathrm{C} C$ をレレーサとして用いている 研究としては, 陸域から海洋への河川を通しての有機態 炭素輸送機構を解明する研究や森林内での炭素循環を評 価する研究について議論が行われた。これらの議論を通 して, それぞれの分野に扔ける着眼点, 研究手法等につ
いて共通点や相違点についての認識を得るのに貢献し た。

\section{学会に「炭素14環境中移行研究連絡会」を設置}

筆者の観点からは, 部会企画セッションで取り上げら れた ${ }^{14} \mathrm{C}$ 環境中移行モデルを用いた安全評価研究が重要 であると思われた。環境中での炭素移行は時間・空間又 ケールが極めて幅広く, 人間が生活する地表面環境に 限ってもその様態の多様性は大きい。それに対して, 個々 の研究が対象にできる範囲は限られており，そこから普 遍性の高い知見を得るのが難しい。このような研究対象

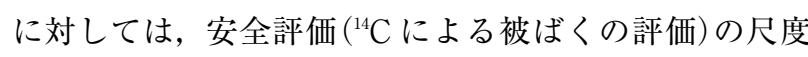
で見た場合の主要な研究対象を明らかにすることがまず 求められ，その際の手段としてモデル計算が有用であ る。現時点では, 個々の機関および研究者が独自の観点 で研究を進めているが，限られた研究資源を有効に活用 するためには，主要な研究対象を明らかにした上で，あ る程度組織立った取組みが必要である。当然, 個々の研 究者のオリジナリティーが尊重されることが前提であ る。モデルを用いたこの研究から原子力分野での研究 ニーズの提言得て, 研究コミュニティーで共通に認識さ れることを望みたい。

この企画セッションでは, IAEA の Environmental Modelling for Radiation Safety (EMRAS) プロジェクト において, 日本原子力研究開発機構が集約した再処理施 設から放出された ${ }^{14} \mathrm{C}$ のメへの取込みに関する実デー 夕を用いたモデル評価が国際的に進められていることが 紹介された。世界の研究を主導するものとして評価され る。近年，欧米において原子力への回帰が明瞭になって きている中，ここ20年ほどの間で減退した欧米の原子力 環境分野の研究にははっきりとした光明はまだ見られな い。一方，中国をはじめとするアジア域では原子力利用 の機運が高まり, 研究活動が活発化しつつある。その中 にあって，これからの10年が我が国の研究資源，すなわ ちこれまでの研究成果, 施設・設備求よび人的資源が最 も活躍できる期間になるように思われる。

この企画セッションを受けて部会内に「炭素14環境中 移行研究連絡会 $\rfloor か ゙$, 研究機関, 大学, 事業者からの参 加を得て設置されたことは特筆される。現時点ではそれ ほど大きな研究コミュニティーではないが，今後さらに 原子力分野に限らず, 関係する研究者の参加を得て, 原 子力分野内外との連携の核として機能することが望まれ る。

(2007年 1 月 6 日 記) 